\title{
Study on Hydrochemical Characteristics of Ordovician Limestone in Jiaozuo Mining Area
}

\author{
Qiaoqiao Su${ }^{1}$, Zhongyuan Yang ${ }^{2}$, Hongfei $\mathrm{Gao}^{3}$, Nayan $\mathrm{Zhao}^{4}$, Liu $\mathrm{Du}^{5}$ \\ 1,2,3,4,5 School of Institute of Resource\& Environment, Henan Polytechnic University, Jiaozuo 454000, Henan, China
}

\begin{abstract}
In order to understand the source of groundwater inrush and its hydrogeochemical evolution path truly, determine the evolution characteristics and development trend of water cycle, and effectively solve the problem of water disaster in mining area. In this paper, Jiaozuo mining area, a typical large water mining area of North China type, is selected as the study area. Taking the Ordovician aquifer in the study area as the research object, the $\mathrm{Ca}^{2+}$ hydrochemical equilibrium model of Ordovician limestone water system is established by analyzing the characteristics of concentration gradient field and the relationship between the hydrochemical ions $\left(\mathrm{Ca}^{2+} 、 \mathrm{~K}^{+}+\mathrm{Na}^{+} 、 \mathrm{Mg}^{2+} 、 \mathrm{Cl}^{-} 、 \mathrm{SO}_{4}{ }^{2-} 、 \mathrm{HCO}_{3}^{-}\right)$and TDS in the mining area, it made a systematic study on the characteristics of Ordovician limestone water circulation, and analyzed the recharge, runoff and discharge characteristics of groundwater in different areas of the mining area. The results show that the Ordovician limestone water in the Jiaozuo mining area has a weak leaching effect in the north and southwest, but a strong leaching effect in the southeast, which shows a runoff characteristic from the north and southwest to the southeast.
\end{abstract}

KEYWORDS: Ordovician limestone water; Conventional ion; Water chemistry; Characteristics of supplementary discharge.

\section{INTRODUCTION}

North China coalfield is an important coal base in China, with a total coal area of about $150000 \mathrm{~km}^{2}$, and its coal production accounts for more than $90 \%$ of the country (e.g. [1]). Due to Caledonian movement at the end of Middle Ordovician and transgression again at the end of Late Carboniferous, the coal measures strata in this area directly covered the thick limestone with strong water abundance, and then developed water conducting structures such as faults in North China type coalfield through multi-stage tectonic movement (e.g. [2] [3]). Jiaozuo mining area, as a typical North China type coal mining area, has complex hydrogeological conditions. Cambrian and Ordovician carbonate rocks with karst fissures are widely exposed in Taihang Mountain Area in the north of the mining area. With the mining activities moving to the deep, Ordovician limestone water lies under the coal measures and distributes in the whole area, with high water head and large water volume, which has become the most threatening water filling source for mining coal seams in the mining area. At present, combining with the regional hydrogeological conditions, many experts and scholars have studied the hydrogeochemistry of ground-water by using hydrochemical characteristics comparison method, isotope method, trace element method and other methods to analyze the hydrochemical characteristics and evolution rules of groundwater (e.g. [4] [10]).

Based on the in-depth analysis of hydrogeological conditions, this paper studies the hydrogeochemical characteristics of the Ordovician limestone water system and establishes the $\mathrm{Ca}^{2+}$ hydrochemical equilibrium model of the Ordovician limestone water system in the Jiaozuo mining area, a typical North China type coal mine area in the piedown of Taihang Mountains. Based on the analysis of the relationship between conventional hydrochemical ions and total dissolved solids, the distribution of aquifer concentration gradient field and $\mathrm{Ca}^{2+}$ water chemical balance characteristics of Ordovician limestone water, the recharge, runoff and discharge characteristics of groundwater in different areas of the mining area are obtained, and the migration mechanism of Ordovician limestone water in typical North China type coal mining area is expounded. This paper expounds the migration mechanism of Ordovician limestone water underground in typical coal mining areas of North China type, which provides scientific basis for preventing and controlling water inrush accidents, effectively protecting groundwater resources and preventing groundwater pollution in mining areas.

\section{OVERVIEW OF THE STUDY AREA}

Jiaozuo Mining Area is located in the northwest of Henan Province, China. It is located in the transition zone between the Taihang Mountains and the North Henan Plain, with the Taihang Mountains in the north and the alluvial and diluvial plain of the Yellow River and Qinhe River in the south. The terrain decreases gradually from northwest to southeast. In Jiaozuo mining area, the Upper Ordovician, Silurian, Devonian, Lower Carboniferous, Jurassic and Cretaceous strata are missing. The exposed strata consist of Archean metamorphic rocks, Sinian quartz sandstone, Cambrian and 
Ordovician carbonate rocks, Carboniferous and Permian coalbearing strata, Triassic sand shale, Neogene sand and mudstone, and Quaternary loose alluvial and diluvial deposits (e.g. [11]). The rivers all originate from the mountainous area in the north of the mining area and flow from northwest to southeast, intersecting with the fault zone of the mining area (e.g. [12]). Because this area is controlled by many groups of high Angle faults, the bedrock strata are cut and broken, resulting in complex regional hydrogeological conditions.
According to the stratigraphic lithology, thickness, water space characteristics and burial conditions, the study area can be divided into four types of water-bearing rock groups, the third, quaternary pore water petrofabric glutenite, Permian sandstone fissure water petrofabric, carboniferous thin limestone karst fissure water petrofabric and the ordovician limestone middle thick layer fracture water-eroded cave water-bearing rock group.

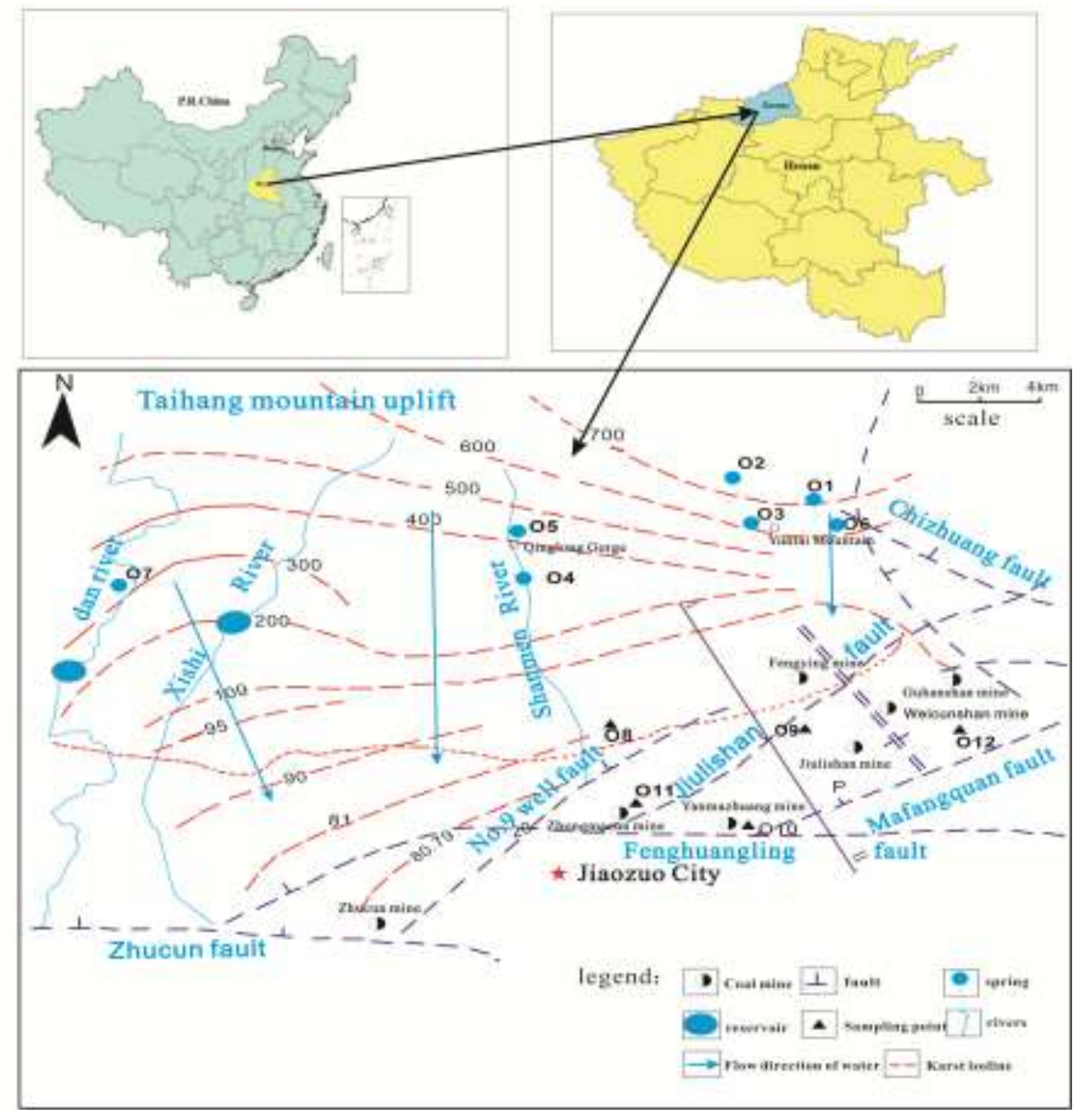

Fig.2-1 Geographical map of Jiaozuo City and map of mining areas

\section{DATA SOURCES AND RESEARCH METHODS}

In this study, 12 samples of Ordovician limestone underground aquifer are collected from groundwater in Jiaozuo Coal Mine Area. The data are shown in Table 3-1, and the specific sampling locations are shown in Figure 2-1, too. Water samples are collected in clean plastic bottles for the determination of stable isotopes and hydrochemical ions. The bottle must be filled with water and properly sealed and labeled. The longitude, latitude, elevation, sampling time and number of bottles of the water sample are recorded .The temperature, conductance, $\mathrm{pH}$ and TDS of water samples are measured in the field. Before extracting the water sample, rinse the plastic bottle and bottle cap with the sample three to five times. Water samples are stored in clean $550 \mathrm{ml}$ plastic bottles while being chemically treated to inhibit REDOX reactions and biochemical effects. The content analysis of each ion is completed in the Key Laboratory of Resources and Environment of Henan Polytechnic University, using Shimadzu ion chromatograph and ICP-MS, with a relative error of $1 \%$. But $\mathrm{HCO}_{3}{ }^{-}$is determined by dilute sulfuric acid - methyl orange titration.

Tabl.3-1. Chemical analyses results of Ordovician limestone water samples

\begin{tabular}{cccccccccc}
\hline Sample number & $\mathrm{K}^{+}+\mathrm{Na}^{+}$ & $\mathrm{Ca}^{2+}$ & $\mathrm{Mg}^{2+}$ & $\mathrm{Cl}^{-}$ & $\mathrm{SO}_{4}^{2-}$ & $\mathrm{HCO}_{3}^{-}$ & $\mathrm{F}^{-}$ & $\mathrm{TDS}^{-}$ \\
\hline $\mathrm{O} 1$ & 4.6 & 62.3 & 26.5 & 1.5 & 20.5 & 289.8 & 0.5 & 413.3 \\
$\mathrm{O} 2$ & 9.85 & 44.6 & 20 & 2 & 26.5 & 206.4 & 0.5 & 317.4 \\
$\mathrm{O} 3$ & 8.2 & 62 & 19 & 3.5 & 31.5 & 237.8 & 1 & 372.2 \\
\hline
\end{tabular}


"Study on Hydrochemical Characteristics of Ordovician Limestone in Jiaozuo Mining Area"

\begin{tabular}{cccccccccc}
\hline O4 & 3.05 & 57.3 & 17.7 & 2.5 & 25 & 207.1 & 1 & 321.3 \\
O5 & 4.55 & 68.2 & 16.7 & 3 & 28 & 240.2 & 1 & 372.8 \\
O6 & 12.8 & 63.1 & 25.8 & 3.5 & 63.5 & 229.4 & 1 & 424.4 \\
O7 & 33.8 & 115.5 & 33.5 & 11.5 & 183.5 & 298.9 & 3.5 & 697.3 \\
O8 & 30.3 & 72.5 & 16.2 & 16 & 52.5 & 248.7 & 2 & 451.2 \\
O9 & 34.3 & 64.9 & 23.4 & 9.5 & 36.5 & 301.8 & 4 & 474 \\
O10 & 17.1 & 64.5 & 24.9 & 7 & 25 & 290.2 & 3 & 435.1 \\
O11 & 13.3 & 59.1 & 15.3 & 5 & 33 & 212.2 & 1.5 & 351.1 \\
O12 & 97.6 & 6.5 & 9.2 & 7 & 145 & 42.4 & 1.5 & 303.7 \\
\hline
\end{tabular}

Note: The water samples were sent to the Key Laboratory of Resources and Environment in Henan Polytechnic University and the State Key Laboratory of Hydrology and Water Resources and Hydraulic Engineering Science in Hohai University.

\section{RESULTS AND DISCUSSION}

A. Characteristics of hydrochemical types in Ordovician limestone water

Piper trigram can directly reflect the distribution characteristics and relative abundance of main conventional ions in different aquifers, and can provide a basis for the hydrochemical changes of groundwater. It is the most widely applied method in hydrogeochemical research at present, and can explain many hydrogeochemical problems (e.g. [13] [14]). The main ions in common components of groundwater are $\mathrm{Na}^{+}+\mathrm{K}^{+}, \mathrm{Ca}^{2+}, \mathrm{Mg}^{2+}, \mathrm{HCO}_{3}{ }^{-}, \mathrm{Cl}^{-}, \mathrm{SO}_{4}{ }^{2-}$ and $\mathrm{CO}_{3}{ }^{2-}$. The Piper trigram consists of two equilateral triangles and a parallelogram, with the left triangle representing the cation concentration and the right triangle representing the anion concentration. The relative content of ions in any water sample is respectively expressed in two triangles, projected in the equilateral parallelogram, and an intersection point is obtained to comprehensively express the ion content in this water sample. Piper trigram is drawn with Ordovician limestone water sample data, as shown in Figure 4-1.

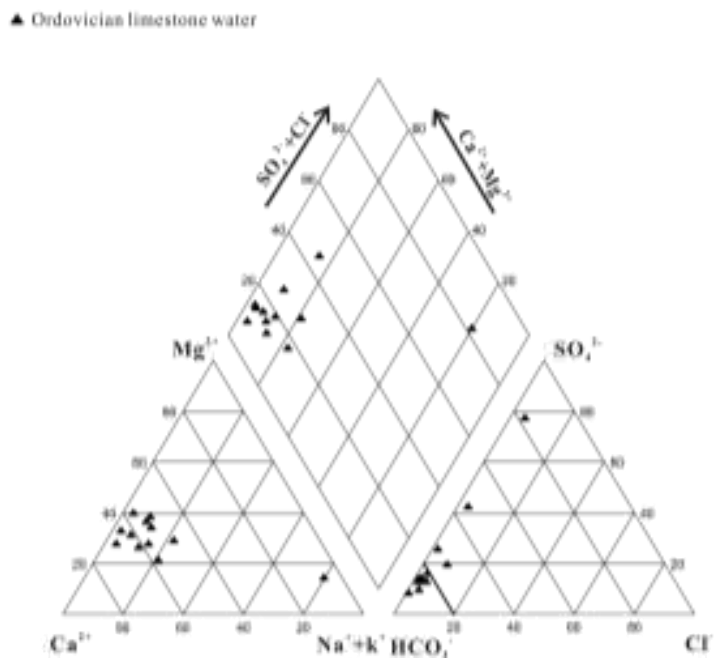

Fig.4-1 Piper diagram of chemical composition of Ordovician limestone water sample

Overall, the distribution of Ordovician limestone water samples is relatively concentrated in the figure, and the hydrochemical types have little change. Among them, the conventional ions are mainly $\mathrm{Ca}^{2+}, \mathrm{Na}^{+}, \mathrm{SO}_{4}{ }^{2-}$ and $\mathrm{HCO}_{3}{ }^{-}$. The sum of cation $\mathrm{Ca}^{2+}$ and $\mathrm{Mg}^{2+}$ in most of the water sample points is greater than $50 \%$, the relative ion content of $\mathrm{CO}_{3}{ }^{2-}$ in anions is almost zero, and the content of $\mathrm{HCO}_{3}{ }^{-}$is generally high. $\mathrm{Ca}-\mathrm{Mg}-\mathrm{HCO}_{3}$ is the main type of Ordovician limestone water quality, followed by $\mathrm{Ca}-\mathrm{Mg}-\mathrm{Na}-\mathrm{HCO}_{3}$. The distribution characteristics of Ordovician limestone water are regular. In the cationic trigram, from the alluvial fan in the north to the alluvial plain of Huangqin River in the south, along the main runoff direction of groundwater, $\mathrm{Na}^{+}+\mathrm{K}^{+}$increases, $\mathrm{Ca}^{2+}$ decreases, while $\mathrm{Mg}^{2+}$ has little change. In the anion trigram, $\mathrm{HCO}_{3}{ }^{-}$decreases while $\mathrm{Cl}^{-}$and $\mathrm{SO}_{4}{ }^{2-}$ increase.

\section{B. Analysis of concentration gradient field}

The limestone water in Jiaozuo mining area is represented by the Ordovician limestone water with strong water-bearing capacity, and the Ordovician limestone constitutes the foundation of coal seam, so it is particularly important to analyze the characteristics of hydrochemical migration. There is a certain relationship between conventional ions and TDS in Ordovician limestone aquifer, and TDS can reflect the change of groundwater concentration (e.g. [15]). Therefore, the contour map can be used to simulate the concentration gradient field of water quality of aquifer in Jiaozuo mining area and analyze the characteristics of aquifer water cycle. According to the theory of water quality gradient field, the TDS is small, the water recharge is sufficient, the retention time of groundwater is short, and the filtration effect with surrounding karst is weak. TDS is large, the flow velocity is 
slow, the water supply is insufficient, and the groundwater retention time is long. In a groundwater circulation system at a certain level, water quality is generally considered to migrate from the region with small TDS to the region with large TDS. The closer the isoline is, the more sufficient the filtration is. The sparser the isoline, the weaker the filtration. Figure 4-2 shows the water quality migration characteristics of Ordovician limestone aquifer in Jiaozuo mining area.

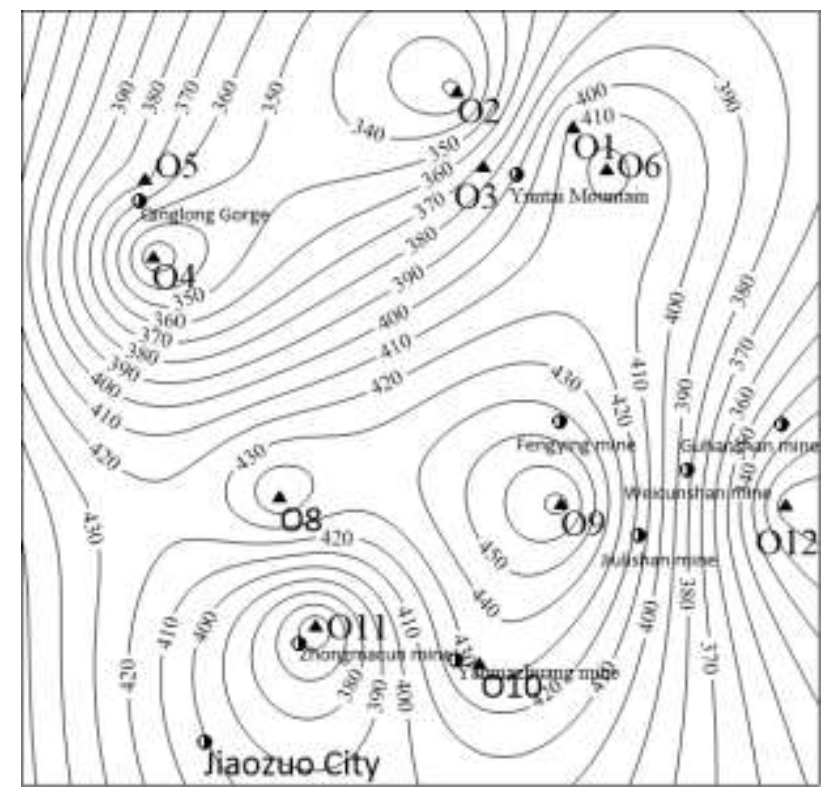

Fig.4-2 Total dissolved solids (TDS) contour of Ordovician limestone aquifer in mining area

The TDS of Ordovician limestone water is smaller in the north and southwest. It is relatively high in the southeast, with a high value of $474 \mathrm{mg} / \mathrm{L}$ in Jiulishan Mine. As the groundwater flows to the southeast, the solubilization is strengthened and the TDS increases gradually. Throughout the mine, the water migrates from northwest to southeast. The TDS in the southeastern part of Ordovician limestone aquifer is larger, the isolines are compact, and the filtration is strong. In the north and southwest, TDS is small, the isolines are sparse, and the filtration is weak.

\section{Chemical equilibrium analysis of $\mathrm{Ca}^{2+}$ in Ordovician limestone water}

Relationship between conventional ions and TDS: Ordovician limestone water is the main source of karst water inrush in Jiaozuo mining area, limestone and dolomite are the main water bearing media. The main water quality type of

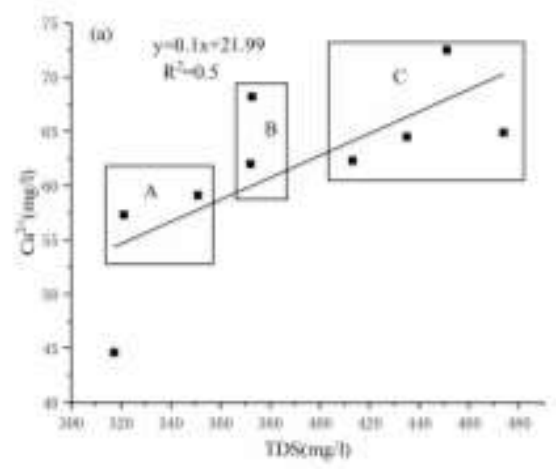

Ordovician limestone is $\mathrm{Ca}-\mathrm{Mg}-\mathrm{HCO}_{3}$, followed by $\mathrm{Ca}-\mathrm{Mg}$ $\mathrm{Na}-\mathrm{HCO}_{3}$. From north to south, $\mathrm{Ca}^{2+}$ and $\mathrm{Mg}^{2+}$ cations are dominant in Ordovician limestone water in the whole mining area, gradually changing into $\mathrm{Ca}^{2+}, \mathrm{Mg}^{2+}$ and $\mathrm{Na}^{+}$dominant Under hydrodynamic conditions, the hydrochemical characteristics of aquifers show their own characteristics from recharge area to runoff area to discharge area. According to the relationship between conventional ions and total dissolved solids, it can be seen that there is a good linear correlation between conventional ions and total dissolved solids in Ordovician limestone water, as shown in Figure 4-3. Therefore, it is of great significance to study the hydrochemical characteristics of Ordovician limestone aquifer system and analyze the relationship between conventional ions and TDS, especially the relationship between $\mathrm{Ca}^{2+}$ and TDS.

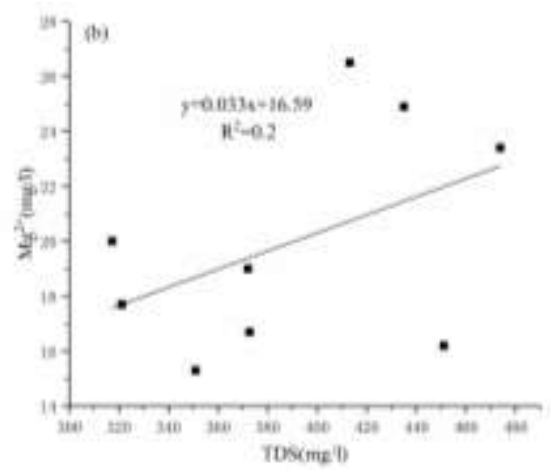



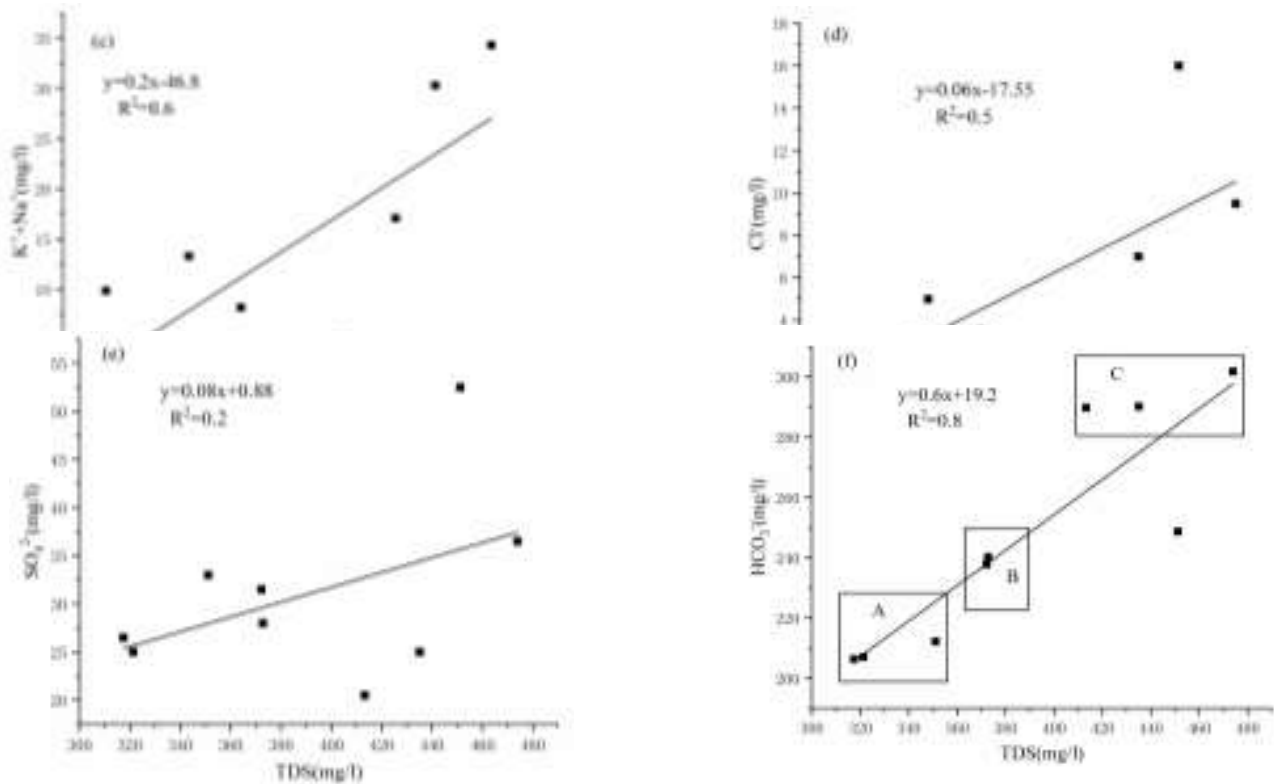

Fig.4-3 Relationship between conventional ion concentration of Ordovician limestone water and total dissolved solids (TDS)

The characteristics of conventional ion migration in groundwater system of Ordovician limestone water in Jiaozuo mining area are as follows:

(1) The content of $\mathrm{K}^{+}+\mathrm{Na}^{+}$in Ordovician limestone water is at a disadvantage, which is often absorbed by plants and adsorbed by clay particles, and has little content in groundwater.

(2) With the increase of TDS, the content of conventional ions in Ordovician limestone water also increased. It can be seen from Figure 3-3 that $\mathrm{R}^{2}$ of $\mathrm{Ca}^{2+}, \mathrm{K}^{+}+\mathrm{Na}^{+}, \mathrm{Cl}^{-}, \mathrm{HCO}_{3}{ }^{-}$and TDS are all greater than 0.5 . This indicates the accuracy and reliability of using TDS index to simulate the groundwater concentration gradient field and analyze its cyclic characteristics in the mining area.

(3) It can be seen from the slope of each conventional ion trend line in Figure 4-3: The slope relation of cation is $\mathrm{k}_{\mathrm{K}^{+}+\mathrm{Na}^{+}}>\mathrm{k}_{\mathrm{Ca}^{2+}}>\mathrm{k}_{\mathrm{Mg}^{2+}}$, so the migration ability of cations in Ordovician limestone water is $\mathrm{K}^{+}+\mathrm{Na}^{+}>\mathrm{Ca}^{2+}>\mathrm{Mg}^{2+}$. The slope relation of anions is $\mathrm{k}_{\mathrm{HCO}_{3}}{ }^{-}>\mathrm{k}_{\mathrm{SO}_{4}{ }^{2-}}>\mathrm{k}_{\mathrm{Cl}^{-}}$, so the migration ability of anions in Ordovician limestone water is $\mathrm{HCO}_{3}{ }^{-}>\mathrm{SO}_{4}{ }^{2-}>\mathrm{Cl}^{-} . \mathrm{HCO}_{3}{ }^{-}$is closely related to $\mathrm{Ca}^{2+}$ in Ordovician limestone water, showing the same migration law.

When the runoff condition is excellent and TDS is low, $\mathrm{Ca}^{2+}$ and $\mathrm{HCO}_{3}{ }^{-}$are accumulated (Figure 4-3 ( $、$ f)-A area);

The TDS is increasing with the path migration of groundwater, When $\mathrm{Ca}^{2+}$ and $\mathrm{HCO}_{3}{ }^{-}$accumulated to a certain extent, calcium carbonate precipitated and the accumulation rate decreased (Figure 4-3 (a、f) -C area); The middle is the transition area（Figure 4-3（a、f）-B area）. Therefore, the water cycle law of Ordovician limestone water system is analyzed by using $\mathrm{Ca}^{2+}$ water chemical balance in Jiaozuo mining area.

Relationship between $\mathrm{Ca}^{2+}$ and $\mathrm{HCO}_{3}{ }^{-}, \mathrm{Ph} \mathrm{HCO}_{3}{ }^{-}$is one of the characteristic ions in Ordovician limestone water system, which is the main manifestation of karst phenomenon in carbonate rocks. When the $\mathrm{HCO}_{3}{ }^{-}$concentration of Ordovician limestone groundwater in Jiaozuo mining area is 206.4-248.7mg/L, the $\mathrm{Ca}^{2+}$ concentration increases with the increase of $\mathrm{HCO}_{3}{ }^{-}$concentration. When the concentration of $\mathrm{HCO}_{3}{ }^{-}$is $248.7 \mathrm{mg} / \mathrm{L}$, the maximum concentration of $\mathrm{Ca}^{2+}$ reaches $72.5 \mathrm{mg} / \mathrm{L}$. When the concentration of $\mathrm{HCO}_{3}{ }^{-}$is ranged from 256 to $300 \mathrm{mg} / \mathrm{L}$, the concentration of $\mathrm{Ca}^{2+}$ decreases with the increase of $\mathrm{HCO}_{3}{ }^{-}$concentration. It can be seen from Figure 4-4 (a) that the concentration of $\mathrm{HCO}_{3}{ }^{-}$up to $256 \mathrm{mg} / \mathrm{L}$ is the mutation point of $\mathrm{Ca}^{2+}$ dissolution in Ordovician limestone water system in the mining area.

Ordovician limestone water is generally alkaline with $\mathrm{pH}$ value between 7.19 and 8.23 in Jiaozuo mining area. When the $\mathrm{pH}$ value is between 7.19 and 7.48 , carbonate is easy to dissolve, the concentration of $\mathrm{CO}_{3}{ }^{2-}$ is dominant in groundwater, and the concentration of $\mathrm{Ca}^{2+}$ accumulates to $68.2 \mathrm{mg} / \mathrm{L}$. When the $\mathrm{pH}$ value is higher than 7.48, the concentration of $\mathrm{Ca}^{2+}$ begins to decrease and precipitation occurs. With the increase of $\mathrm{pH}$ value, the precipitation becomes more complete until the concentration of $\mathrm{Ca}^{2+}$ slows down (Figure 4-4 (a)). 

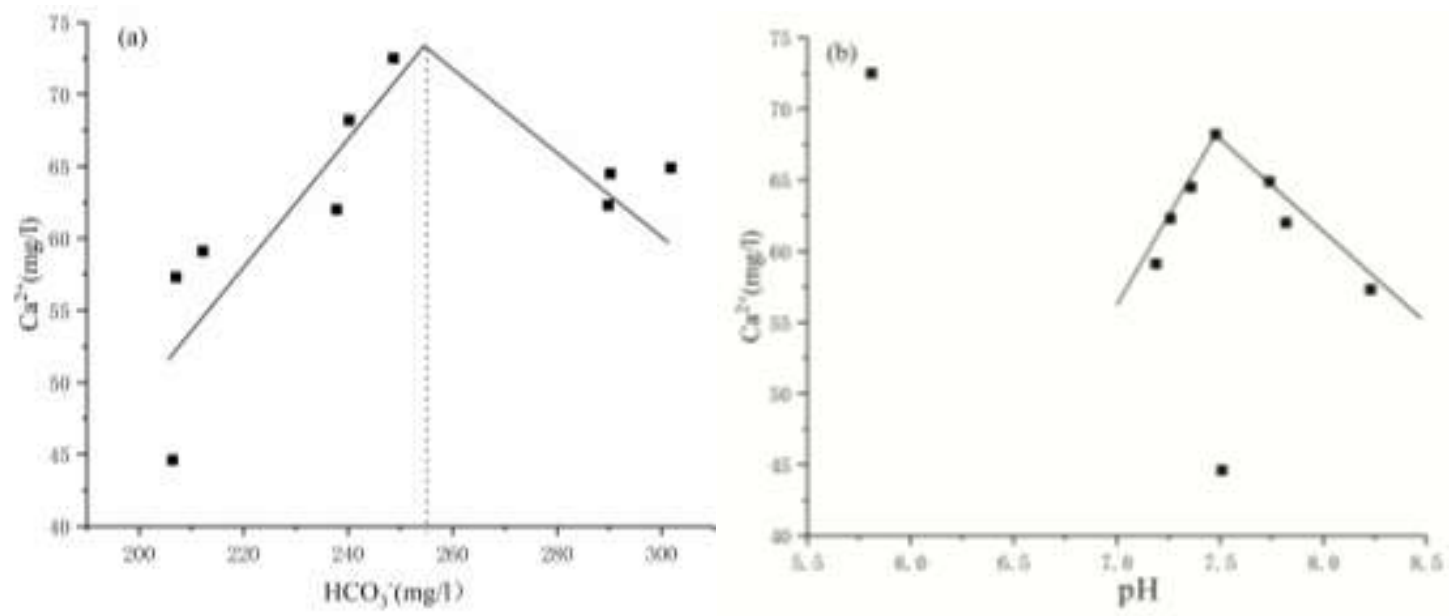

Fig. 4-4 Relationship between $\mathrm{Ca}^{2+}$ vs $\mathrm{HCO}_{3}{ }^{-}$, pH in Ordovician limestone water system

Chemical equilibrium model of $\mathrm{Ca}^{2+}$ : According to the chemical equilibrium model of $\mathrm{Ca}^{2+}$ in karst water system established by experts and scholars before (e.g. [16] [17]), Combined with the actual situation of Jiaozuo mining area, the chemical equilibrium model of $\mathrm{Ca}^{2+}$ in Ordovician limestone water was established.

In the recharge area of the open system, the free exchange of atmospheric precipitation, surface water and $\mathrm{CO}_{2}$ will lead to the continuous dissolution of $\mathrm{CaCO}_{3}$; In the runoff area of the closed system, the Ordovician limestone water continuously erodes the $\mathrm{CaCO}_{3}$ in the system until the equilibrium between dissolution and precipitation is reached; Assuming that there is no completely closed environment, according to the principles of thermodynamics and hydrochemical equilibrium, there is an equilibrium between groundwater and atmosphere in an open system, and the amount of $\mathrm{CO}_{2}$ dissolved in water depends the $\mathrm{P}_{\mathrm{CO}_{2}}$. Therefore, the calculation formula of $\mathrm{Ca}^{2+}$ saturation is given in the open system

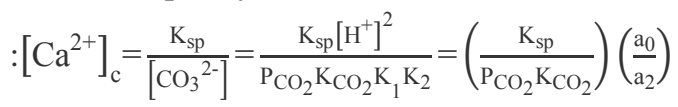

Where: $\mathrm{a}_{0}$ is the percentage of $\mathrm{H}_{2} \mathrm{CO}_{3}$ in total carbonic acid:

$$
\mathrm{a}_{0}=\frac{\left[\mathrm{H}_{2} \mathrm{CO}_{3}\right]}{\mathrm{DIC}}=\left(1+\frac{\mathrm{K}_{1}}{\left[\mathrm{H}^{+}\right]}+\frac{\mathrm{K}_{1} \mathrm{~K}_{2}}{\left[\mathrm{H}^{+}\right]^{2}}\right)^{-1} \times 100 ;
$$

$\mathrm{a}_{2}$ is the percentage of $\mathrm{CO}_{3}{ }^{2-}$ in total carbonic acid:

$$
\mathrm{a}_{2}=\frac{\left[\mathrm{CO}_{3}{ }^{2-}\right]}{\mathrm{DIC}}=\left(1+\frac{\left[\mathrm{H}^{+}\right]}{\mathrm{K}_{1} \mathrm{~K}_{2}}+\frac{\left[\mathrm{H}^{+}\right]}{\mathrm{K}_{2}}\right)^{-1} \times 100 ;
$$

$\left[\mathrm{Ca}^{2+}\right]_{\mathrm{c}}$ is The calculated $\mathrm{Ca}^{2+}$ saturation concentration value.

The first ionization constant $\mathrm{K}_{1}$ :

$$
\mathrm{K}_{1}=\frac{\left[\mathrm{H}^{+}\right]\left[\mathrm{HCO}_{3}^{-}\right]}{\left[\mathrm{H}_{2} \mathrm{CO}_{3}\right]}
$$

The second ionization constant $\mathrm{K}_{2}$ :

$$
\mathrm{K}_{2}=\frac{\left[\mathrm{H}^{+}\right]\left[\mathrm{CO}_{3}{ }^{2-}\right]}{\left[\mathrm{HCO}_{3}{ }^{-}\right]}
$$

The calculated $\mathrm{Ca}^{2+}$ saturation concentration value was subtracted from the measured $\mathrm{Ca}^{2+}$ concentration value:

$$
\Delta\left[\mathrm{Ca}^{2+}\right]=\left[\mathrm{Ca}^{2+}\right]_{\mathrm{m}}-\left[\mathrm{Ca}^{2+}\right]_{\mathrm{c}}
$$

Where: $\left[\mathrm{Ca}^{2+}\right]_{\mathrm{m}}$ is the measured $\mathrm{Ca}^{2+}$ concentration value. So: $\Delta\left[\mathrm{Ca}^{2+}\right]<0, \mathrm{CaCO}_{3}$ dissolved, Ordovician limestone water is in the replenishing area;

$\Delta\left[\mathrm{Ca}^{2+}\right]=0, \mathrm{CaCO}_{3}$ precipitation, Ordovician limestone water in the runoff area;

$\Delta\left[\mathrm{Ca}^{2+}\right]>0, \mathrm{CaCO}_{3}$ precipitation, Ordovician limestone water in the drainage area.

Characteristics of $\mathrm{Ca}^{2+}$ water chemical equilibrium: According to the $\mathrm{Ca}^{2+}$ water chemical balance, the $\mathrm{Ca}^{2+}$ saturation concentration difference of eight Ordovician limestone water sample points in Jiaozuo mining area is calculated respectively. As shown in Figure 4-5, the contour map of $\mathrm{Ca}^{2+}$ saturation concentration difference in Ordovician limestone water is made, it can be seen from the figure:

(1) The $\Delta\left[\mathrm{Ca}^{2+}\right]$ value of Ordovician limestone water gradually increases from the north and southwest to the southeast. The Taihangshan in the northern part of the mining area and Zhongmacun mines are distributed in the low value zone of $\Delta\left[\mathrm{Ca}^{2+}\right]$. The low value zone of Ordovician limestone water $\Delta\left[\mathrm{Ca}^{2+}\right]$ is distributed in the northern of Taihang Mountains, and its minimum value is $-0.048 \mathrm{~mol} / \mathrm{L}$. This indicates that there is a amicable hydraulic connection between the Ordovician tectonic layer and atmospheric precipitation, the Ordovician limestone water alternation is rapid, the hydrogeochemical action is weak, and the mountainous area is excellent replenishment source of the Ordovician limestone water. The low value zone of $\Delta\left[\mathrm{Ca}^{2+}\right]$ in Ordovician limestone water is distributed in Zhongmacun mine, and its minimum value is $-0.052 \mathrm{~mol} / \mathrm{L}$. This area is the intersection zone of many faults. The fault structural zone extends to the Ordovician aquifer. The newly formed water supplies the Ordovician limestone aquifer quickly, which leads to the equilibrium of $\mathrm{CaCO}_{3}$ to the direction of dissolution, showing the characteristics of recharge. Jiulishan mine has a high value, and the maximum value of $\Delta\left[\mathrm{Ca}^{2+}\right]$ is $-0.009 \mathrm{~mol} / \mathrm{L}$, close to $0 \mathrm{~mol} / \mathrm{L}$, which indicates that $\mathrm{CaCO}_{3}$ tends to be in equilibrium, the exchange between aquifer and 
outside is weakened, and Ordovician limestone water shows runoff characteristics. In a word, the recharge characteristics of Ordovician limestone water change from north and southwest to Southeast.

(2) From the perspective of Jiaozuo mining area as a whole, the $\Delta\left[\mathrm{Ca}^{2+}\right]$ isoline and TDS isoline of Ordovician limestone water are similar, and TDS gradually increases from the north, southwest to southeast of the mining area.
With the increase of $\Delta\left[\mathrm{Ca}^{2+}\right]$ value, the actual dissolution of calcite gradually increases, which is close to the equilibrium state. The judgment result of $\Delta\left[\mathrm{Ca}^{2+}\right]$ value is consistent with the TDS, which provides a theoretical basis for the analysis of karst water supply, runoff and discharge by using conventional hydrochemical ion in the mining area in the future.

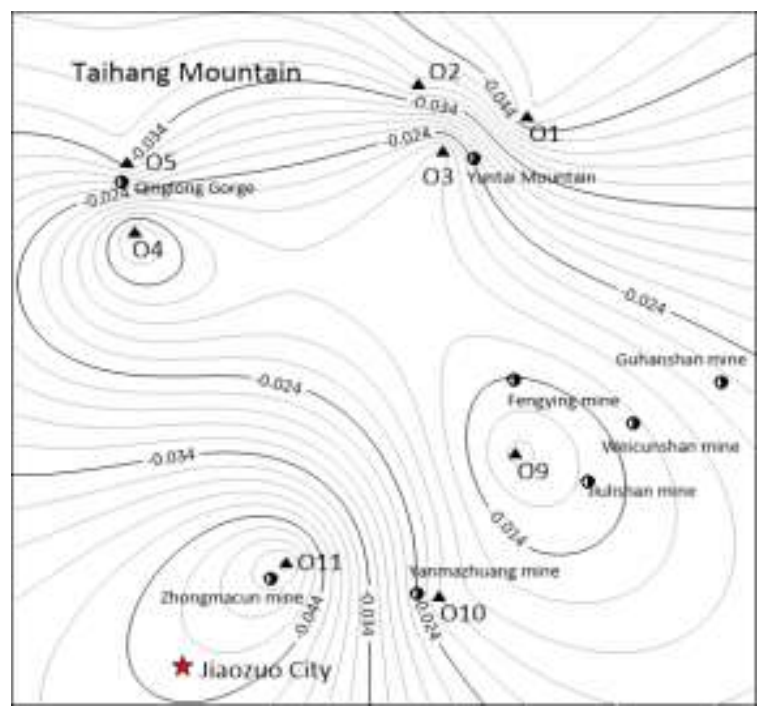

Fig.4-5 $\Delta\left[\mathrm{Ca}^{2+}\right]$ contour of Ordovician limestone aquifer in mining area

\section{CONCLUSION}

Based on the groundwater chemical composition data, the hydrogeochemical characteristics of Ordovician limestone water system were studied, and the linear relationship between conventional ions and total dissolved solids TDS in Ordovician limestone water was analyzed. According to the theory of hydrochemical equilibrium of $\mathrm{Ca}^{2+}$ in groundwater, the model of $\mathrm{Ca}^{2+}$ hydrochemical equilibrium is established in Ordovician limestone water system, and the characteristics of $\mathrm{Ca}^{2+}$ hydrochemical equilibrium of Ordovician limestone water system in mining area are quantitatively analyzed, it is determined that the dissolution and filtration of Ordovician limestone water is weak in the north and southwest, and strong in the southeast. It is found that the recharge characteristics of Ordovician limestone water in the mining area turn to the runoff characteristics in the southeast from the north and southwest, which reflects the recharge, runoff and discharge areas of Ordovician limestone water to a certain extent. With the increase of mining depth, the abundant Ordovician limestone water in the deep has become a major security hidden trouble in the normal production of the mining area. When the coal seam is mined to the fault distribution section, the confined water pressure of the coal mine floor increases, and the risk of water inrush increases. Coal mines should strengthen the monitoring of water level and pressure, establish the dynamic observation network of karst water and take timely measures to prevent water disasters, so as to avoid water inrush caused by karst water.

\section{REFERENCES}

1. Liu D. 2015. Mechanism and early warning technology of mine water inrush in North China type coalfield [D]. China University of Mining and Technology (Beijing).

2. Li Q and L Zhai, et al. 2012. Study on Aquifer Damage Mode of Coal Mining in North China Coalfield [J]. Coal Geology of China ,24(07):38-43.

3. Wu Q, S Zhao and S Dong, et al. 2012. Analysis on the Modification Technology of "Coal Mine Safety Regulations" (Water Prevention and Control) [J]. Coal Geology of China, 24(07):34-37+47.

4. Huang P, Chen J and Ning C. 2012. Hydrogen and Oxygen Isotope Analysis of Groundwater in Jiaozuo Mine Area [J]. Journal of China Coal Society, 37(05):770-775.

5. Chen L, L Wan and F Zhang, et al. 2015. Characteristics of hydraulic connection between aquiferous rock groups in Jiaozuo mining area [J]. South-to-North Water Transfer and Water Science and Technology, 13(02):330-333.

6. Sacchi, E., et al. 2021Tracing groundwater circulation in a valuable mineral water basin with geochemical and isotopic tools: the case of FERRARELLE, Riardo basin, Southern Italy. Environmental geochemistry and health.

7. Zhang, H., et al. Identification of hydrogeochemical processes and transport paths of a multi-aquifer 
system in closed mining regions. JOURNAL OF HYDROLOGY. 589(125344).

8. Chen L, D Xu and Y Liu, et al. 2017. Hydrogeochemical simulation of main water-inrush aquifers in Suxian mining area [J]. Journal of Anhui University of Science and Technology (Natural Science Edition), 37(06):27-33.

9. KESHARI, S.D.D.A., Hydrogeochemical evaluation of high-fluoride groundwaters: a case study from Mehsana District, Gujarat, India. Hydrological Sciences Journal, 2006.51(6) :1149 1162.

10. Jiang X. 2020. Study on reverse simulation of hydrogeochemistry of Cambrian limestone aquifer in Pingdingshan mining area $[\mathrm{J}]$. Groundwater, 42(06):1-41.

11. Nan L. 2018. Study on dynamic change and numerical simulation of karst water level after emission reduction in Jiaozuo mine drainage [D]. Henan Polytechnic University.

12. Chen L, L Wan and F Zhang, et al. 2015.Characteristics of hydraulic connection between aquiferous rock groups in Jiaozuo mining area [J]. South-to-North Water Transfer and Water Science and Technology, 13(02):330-333.

13. Youngsook H, Tsoi M Y, Zaitsev A, et al. The fluvial geochemistry of the rivers of Eastern Siberia: I.tributaries of the Lena River draining the sedimentary platform of the Siberian Craton. Geochimica et Cosmochimica Acta,1998.62(10).

14. Huang, $P$ and $X$ Wang, Piper-PCA-Fisher Recognition Model of Water Inrush Source: A Case Study of the Jiaozuo Mining Area. GEOFLUIDS, 2018(UNSP 9205025).

15. Shen Z. 1983. Fundamentals of Hydrogeochemistry (I). Hydrogeology and Engineering Geology, (03):54-57.

16. Bureau of Hydrogeology of General Administration of Coal Geology of China (Ed.). 1999. Research on Coal Hydrogeology and Engineering Geology. Xuzhou: China University of Mining and Technology Press.

17. Chen L, H Gui and Y Hu, et al. 2003. Study on Hydrochemical Characteristics of Karst Water in Coal Seam Floor in Northern Anhui Mining Area [J]. Coal Geology \& Exploration, (02):27-30. 